Jurnal Medicoeticolegal dan Manajemen Rumah Sakit, 6 (1): 35-44, April 2017

Website: http://journal.umy.ac.id/index.php/mrs

DOI: $10.18196 /$ jmmr.6125

\title{
Pengaruh Pelatihan SBAR Role-Play terhadap Skill Komunikasi Handover Mahasiswa Kebidanan
}

\author{
Kharisah Diniyah* \\ *Penulis Korespondensi: Kharsah.unisa@gmail.com \\ *Prodi Kebidanan Universitas 'Aisyiah, Yogyakarta, Indonesia

\begin{tabular}{l}
\hline $\boldsymbol{I} \boldsymbol{N} \boldsymbol{D} \boldsymbol{X} \boldsymbol{I} \boldsymbol{N} \boldsymbol{G}$ \\
\hline Keywords: \\
Effective \\
Communication; \\
Situation Background \\
Assessment \\
Recommendation; \\
Handover \\
Communication Skill
\end{tabular}

\begin{abstract}
A B S T R A C T
Effective communication is a component in patient safety standards, one of which is implemented in the handover activity. One of the widely used standard is the SBAR (Situation Background Assessment Recommendation). This study uses a quasi experiment research design with a one-group pre-post test design. Respondents in this study are 29 students from 2nd and 3rd year students of midwifery who are conducting obstetrics clinical practice. The data collection is done by observation, and analyzed using the Wilcoxon Match Pairs Test. This study indicates that effective communication role play using the SBAR method can improve effective communication skills at the time of handover and will give better results if done using real cases. So SBAR communication methods can be used as an effective communication standard that can be applied at the time of handover.
\end{abstract}

Kata kunci:

Komunikasi Efektif;

Situation Background

Assessment

Recommendation; Skill

Komunikasi Handover
Komunikasi efektif merupakan salah satu komponen dalam standar patien safety, dimana salah satunya diterapkan dalam kegiatan handover. Diperlukan standar komunikasi efektif, salah satunya menggunakan SBAR (Situation Background Assessment Recommendation). Penelitian ini bertujuan untuk mengetahui pengaruh role play terhadap skill komunikasi efektif pada mahasiswa kebidanan saat melakukan handover. Penelitian ini menggunakan rancangan penelitian quasi experiment dengan onegroup pre-post test design. Responden pada penelitian ini adalah mahasiswa kebidanan tahun ke 2 dan ke 3 yang sedang melaksanakan praktik klinik kebidanan sebanyak 29 orang. Penelitian ini menemukan bahwa role play komunikasi efektif menggunakan metode SBAR dapat meningkatkan skill komunikasi efektif pada saat melakukan handover.

C 2017 JMMR. All rights reserved

Article history: Received 7 Jun 2016; Revised 25 Okt 2016; Accepted 13 Des 2016

\section{PENDAHULUAN}

Keselamatan pasien merupakan komponen penting dalam peningkatkan kualitas dan mutu pelaksanaan layanan kesehatan. Penyampaian informasi tidak tepat yang dapat menimbulkan medical error sering terjadi saat pelaksanaan handover, yang dilakukan oleh dokter kepada perawat, atau sesama perawat di waktu pergantian jaga, saat dokter penanggung jawab turun jaga, atau saat pasien dipindahkan dari unit lain, maupun antar tempat pelayanan kesehatan. $-\frac{1}{1}$

Salah satu upaya yang dilakukan oleh Pemerintah Indonesia untuk menjaga kualitas layanan melalui kementrian kesehatan dengan mengeluarkan undangundang tentang rumah sakit, salah satunya UU no 44 tahun Rumah Sakit, Pasal 43 ayat (1) mewajibkan Rumah Sakit menerapkan standar keselamatan pasien. Standar yang berfokus pasien dalam JCI disebutkan pada Sasaran Internasional Keselamatan Pasien (SIKP) nomor 2 yaitu meningkatkan komunikasi yang efektif.-

Upaya yang dilakukan JCI untuk mengurangi dampak akibat penyampaian dan penerimaan informasi yang tidak tepat yaitu dengan memperkenalkan metode komunikasi efektif yang dapat digunakan dalam handover, dengan komunikasi terstruktur disebut SBAR (Situation Background Assessment and Recommendation). Penggunaan komunikasi dengan metode SBAR tidak hanya meningkatkan mutu pelayanan, tetapi juga dapat meningkatkan kualitas handover yang akan menekan angka medical error. ${ }^{-}$

Praktik klinik merupakan salah satu metode pembelajaran yang termasuk dalam problem base learning (PBL) yang banyak digunakan oleh institusi pendidikan kesehatan, Hal ini dipilih karena melatih calon tenaga kesehatan dalam menyelesaikan masalah kesehatan dan menganalisa kebutuhan pasen, dengan 
menerapkan pengetahuan, yang kemudian dapat diterapkan saat bertemu dengan kasus nyata, sehingga dapat meningkatkan pengetahuan dan kompetensinya. 4

\section{METODE PENELITIAN}

Penelitian ini merupakan penelitian kuantitatif dengan menggunakan rancangan penelitian quasi experiment dengan times series design, menggunakan analisa Wilcoxon Match Pairs Test ${ }^{5}$. Subjek pada penelitian ini adalah mahasiswa kebidanan jenjang D III tahun ke 2 dan ke 3 yang telah mengikuti mata kuliah asuhan kebidanan pada ibu nifas, dan melaksanakan praktik klinik kebidanan di bangsal nifas.

\section{HASIL DAN PEMBAHASAN}

Karakteristik responden pada penelitian ini dilihat dari usia, tahun yang sedang ditempuh, suku, pengalaman mengikuti dan melaksanakan handover, dan bentuk komunikasi efektif yang pernah diperkenalkan di pendidikan. Tabel 1 menunjukkan gambaran karakteristik 29 orang responden dimana $63,1 \%$ berusia 20 tahun atau lebih, 72,4\% suku jawa. Sebanyak 63,1\% merupakan mahasiswa kebidanan jenjang D III yang sedang menempuh pendidikan tahun ke 3 dan 37,9\% merupakan mahasiswa yang sedang menempuh pendidikan tahun ke 2. Kemampuan komunikasi efektif pada mahsiswa kebidanan tahun ke 2 maupun ke 3 sebesar $96.55 \%$ termasuk dalam kategori kurang baik, dan hanya 1 mahasiswa di tahun ke 2 yang termasuk dalam kategori baik. Terdapat pengaruh role play terhadap kemampuan skill komunikasi termasuk dalam kategori baik sebanyak 3 dari 8 orang $(27,27 \%)$ pada mahasiswa tahun ke 2, dan pada mahasiswa tahun ke 3 sebanyak 15 dari 18 orang $(83,34 \%)$.

Tabel 1. Gambaran distribusi frekwensi karakteristik responden

\begin{tabular}{|c|c|c|c|}
\hline No & Karakteristik Responden & $\mathbf{N}$ & $\%$ \\
\hline \multirow[t]{4}{*}{1} & Usia & & \\
\hline & $<20$ tahun & 11 & 37,9 \\
\hline & $\geq 20$ tahun & 18 & 63,1 \\
\hline & Total & 29 & 100 \\
\hline \multirow[t]{4}{*}{2} & Suku Bangsa & & \\
\hline & Jawa & 21 & 72.4 \\
\hline & Bukan Jawa & 8 & 27,6 \\
\hline & Total & 29 & 100 \\
\hline \multirow[t]{4}{*}{3} & Tahun Yang Ditempuh & & \\
\hline & Tahun ke 2 & 11 & 37,9 \\
\hline & Tahun ke 3 & 18 & 63,1 \\
\hline & Total & 29 & 100 \\
\hline \multirow[t]{4}{*}{4} & Pengalaman Mengikuti Handover & & \\
\hline & Pernah & 29 & 100 \\
\hline & Belum pernah & 0 & 0 \\
\hline & Total & 29 & 100 \\
\hline \multirow[t]{4}{*}{5} & Pengalaman Melaksanakan Handover & & \\
\hline & Pernah & 24 & 82,8 \\
\hline & Belum pernah & 5 & 17,2 \\
\hline & Total & 29 & 100 \\
\hline
\end{tabular}


Tabel 2. Perbandingan skill komunikasi efektif sebelum-sesudah diberikan pembelajaran role play berdasar tahun pendidikan

\begin{tabular}{|c|c|c|c|c|c|c|}
\hline & & \multicolumn{4}{|c|}{ Tahun Pendidikan } & \multirow{3}{*}{$P$} \\
\hline & & \multicolumn{2}{|c|}{ Ke 2} & \multicolumn{2}{|c|}{ Ke 3} & \\
\hline & & $\mathrm{n}$ & $\%$ & $\mathrm{n}$ & $\%$ & \\
\hline \multirow[t]{2}{*}{ Skill Komunikasi Pre Test } & kurang baik & 10 & 34.48 & 18 & 62.07 & 0,193 \\
\hline & Baik & 1 & 3.45 & 0 & 0 & \\
\hline Total & & 11 & 37.93 & 18 & 62.07 & \\
\hline \multirow[t]{2}{*}{ Skill Komunikasi Post Test 1} & kurang baik & 8 & 27.59 & 3 & 10.34 & 0.003 \\
\hline & Baik & 3 & 10.35 & 15 & 52.72 & \\
\hline Total & & 11 & 37.93 & 18 & 62.07 & \\
\hline Skill Komunikasi Post Test 2 & Baik & 11 & 37.93 & 18 & 62.07 & - \\
\hline Total & & 11 & 37.93 & 18 & 62.07 & \\
\hline
\end{tabular}

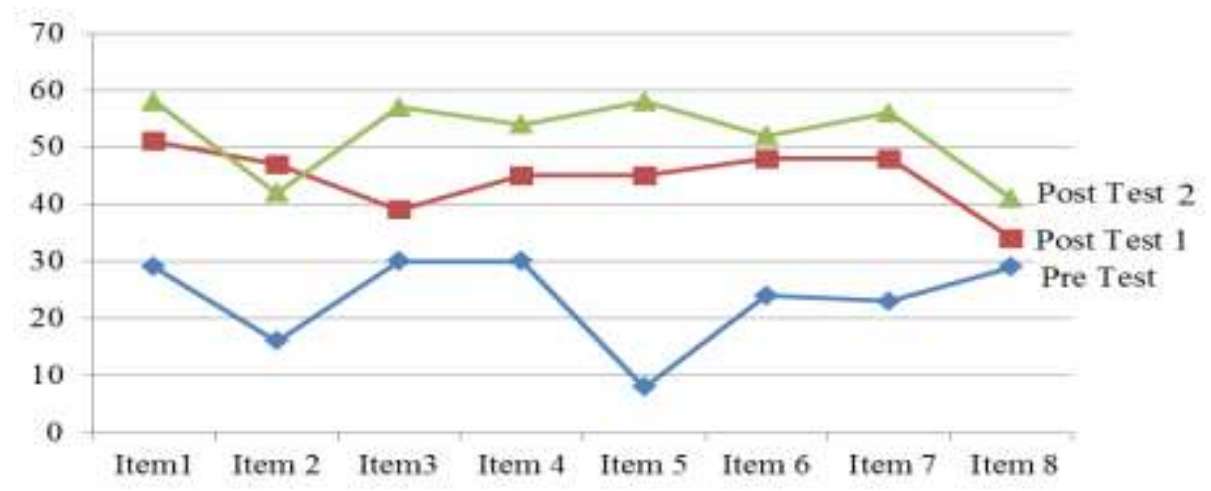

Gambar 1. Grafik Skor Rata-Rata Komunikasi Efektif Pada Pelaksanaan Handover berdasar Item Lembar Observasi

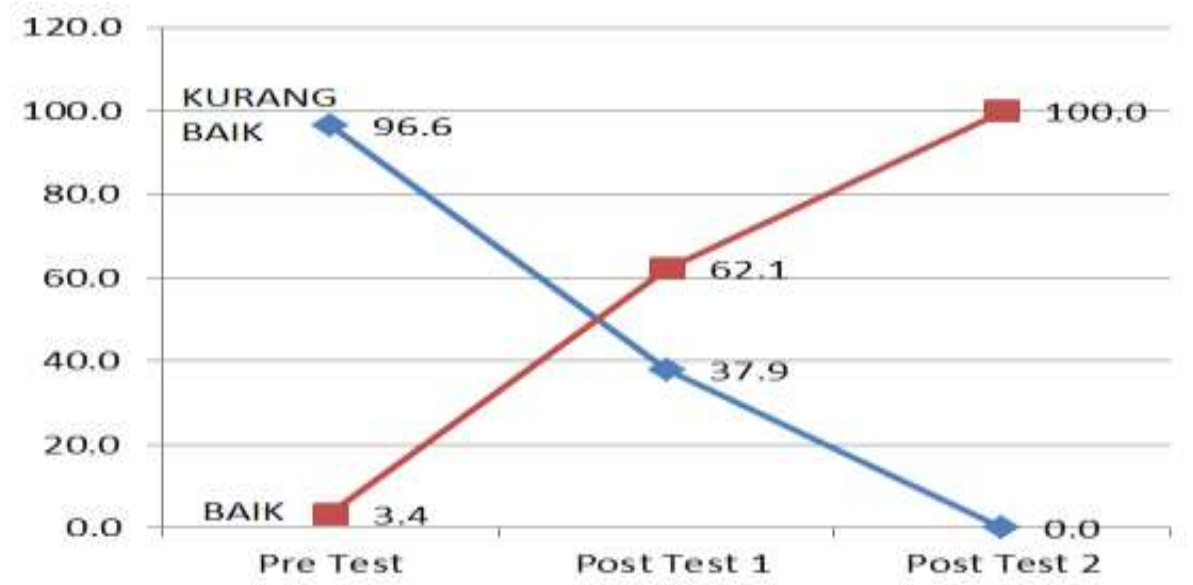

Gambar 2. Grafik rata-rata skill komunikasi efektif pada handover oleh mahasiswa kebidanan jenjang D III pre-post test role-play metode SBAR 
Observasi pelaksanaan komunikasi efektif menggunakan metode SBAR pada handover terdiri dari 8 item, terdiri dari item 1 persiapan, item 2 menjelaskan identitas pemberi pada penerima handover, item 3 komponen Situation (S), item 4 komponen Background (B), item 5 komponen Assesment (A), item 6 komponen Recomenddation (R), item 7 konfirmasi informasi, item 8 sistematik pelaksanaan. Hasil observasi menunjukkan perubahan berupa kenaikan skor antara pre test dengan post test 1 , dan kenaikan skor dari post test 1 dengan post test 2 , kecuali item 2 berupa menjelaskan identitas pemberi pada penerima handover mengalami kenaikan skor pre test 16 menjadi 47 pada post test 1 , akan tetapi mengalami penurunan pada post test 2 menjadi 42 .

Hasil pre test skill komunikasi efektif pada mahasiswa kebidanan sebelum diberikan role-play menunjukan 96,6\% termasuk dalam kategori kurang baik dan 3,4\% dalam kategori baik. Setelah diberikan perlakuan berupa pemberian materi dan simulasi komunikasi efektif metode SBAR pada saat handover, tampak dari gambar 3 terdapat peningkatan skill komunikasi dimana seluruh mahasiswa memiliki kemampuan melakukan komunikasi efektif pada saat timbang terima termasuk dalam kategori baik.

Berdasarkan tabel 3 menunjukkan hasil pengamatan menggunakan lembar observasi skill komunikasi efektif, $28(96,6 \%)$ orang terdiri dari 5 orang $(17,2 \%)$ mahasiswa yang belum pernah dan 24 orang $(82,8 \%)$ yang sudah pernah melakukan handover memiliki skill komunikasi efektif dalam kategori kurang baik, dan hanya 1 orang $(3,4 \%)$ termasuk dalam kategori baik sebelum diberikan perlakuan berupa pembelajaran roleplay komunikasi efektif dengan menggunakan metode SBAR pada saat handover. Terjadi peningkatan kemampuan komunikasi efektif setelah diberikan pembelajaran role-play komunikasi efektif dan melaksanakan simulasi pada kasus nyata baik dikelompok yang belum memiliki pengalaman melakukan handover maupun yang sudah termasuk dalam kategori baik. Data yang ada dalam penelitian ini berjumlah kurang dari 50, sehingga uji homogenitas yang dipilih adalah menggunakan Shaphiro-Wilk.

Tabel 3. Perbandingan skill komunikasi efektif pada mahasiswa yang memiliki pengalaman melakukan handover pada pre-post role-play dengan metode SBAR

\begin{tabular}{|c|c|c|c|c|c|c|c|c|}
\hline & \multicolumn{8}{|c|}{ Pengalaman Melaksanakan Handover } \\
\hline & & \multicolumn{2}{|c|}{ belum pernah } & \multicolumn{2}{|c|}{ sudah pernah } & \multicolumn{2}{|c|}{ Total } & \multirow[t]{2}{*}{$P$} \\
\hline & & $\mathbf{N}$ & $\%$ & $\mathbf{N}$ & $\%$ & $\mathbf{N}$ & $\%$ & \\
\hline \multirow{2}{*}{ Pre Test } & kurang baik & 5 & 17.2 & 23 & 79.3 & 28 & 96.6 & 0.64 \\
\hline & baik & 0 & 0.0 & 1 & 3.4 & 1 & 3.4 & \\
\hline \multicolumn{2}{|c|}{ Total } & 5 & 17.2 & 24 & 82.8 & 29 & 100 & \\
\hline \multirow{2}{*}{ Post Test 1} & kurang baik & 1 & 3.4 & 10 & 34.5 & 11 & 37.9 & 0.36 \\
\hline & baik & 4 & 13.8 & 14 & 48.3 & 18 & 62.1 & \\
\hline \multicolumn{2}{|c|}{ Total } & 5 & 17.2 & 24 & 82.8 & 29 & 100 & \\
\hline Post Test 2 & baik & 5 & 17.2 & 24 & 82.8 & 29 & 100.0 & - \\
\hline \multicolumn{2}{|c|}{ Total } & 5 & 17.2 & 24 & 82.8 & 29 & 100 & \\
\hline
\end{tabular}

Tabel 4. Hasil analisa uji normalitas data pada lembar observasi skill komunikasi efektif

\begin{tabular}{cccc}
\hline & $\mathbf{N}$ & $\boldsymbol{p}$ & Ket \\
\hline Pre Test & 29 & .002 & Tidak bermakna \\
Post Test 1 & 29 & .026 & Tidak bermakna \\
Post Test 2 & 29 & .002 & Tidak bermakna \\
\hline
\end{tabular}


Tabel 5. Hasil analisa uji Wilcoxon pada Skill Komunikasi Efektif Metode SBAR pada Handover seselum dan sesudah dilakukan Role-Play

\begin{tabular}{lccc}
\hline & N & MeAN (minimum-maksimum) & $P$ \\
\hline Nilai Pre Test- Post Test 1 & 29 & $6(4-13)$ & 0.000 \\
Nilai Pre Test- Post Test 2 & 29 & $13(6-13)$ & 0.000 \\
Nilai Post Test 1- Post Test 2 & 29 & $14(12-16)$ & 0.001 \\
\hline
\end{tabular}

Berdasar tabel 4 diperoleh nilai $\mathrm{P} 0.002$ pada pre test, 0.026 pada post test 1 , dan 0.002 pada post test 2 , hal ini menunjukkan bahwa nilai $\mathrm{P}$ hitung $<0.05$ dan dapat disimpulkan bahwa distribusi data pada penelitian ini tidak normal, sehingga uji beda menggunakan uji nonparametric yaitu Wilcoxon. Tabel 5 menunjukkan hasil nilai $\mathrm{P} 0.001$ sehingga $\mathrm{P}<0.05$, dengan demikian dapat disimpulkan bahwa terdapat perbedaan yang bermakna pada skill komuniksi efektif metode SBAR saat handover sebelum dengan sesudah diberikan pembelajaran dengan role-play.

Skill komunikasi efektif pada mahasiswa kebidanan didapati 1 orang memiliki kemampuan kurang baik, 10 orang tidak mengalami perubahan yang terdiri dari 1 orang termasuk dalam kategori baik dan 9 orang dalam kategori kurang baik sebelum diberi perlakuan, dan 18 orang termasuk dalam kategori baik setelah mendapatkan perlakuan berupa pembelajaran role-play komunikasi efektif metode SBAR. Setelah diberikan perlakuan kedua berupa simulasi komunikasi efektif dengan menggunakan kasus nyata pada saat handover diperoleh hasil 28 orang mengalami perubahan dan 1 orang tetap memiliki skill komunikasi efektif dalam kategori baik.

\section{Karakteristik Responden}

Komunikasi merupakan hal yang sangat penting dalam menciptakan kerjasama antar tim guna tercapainya pelayanan kesehatan yang optimal. Selain itu komunikasi juga dapat membangun suasana dan hubungan kerja yang positif ${ }^{3}$. Ketrampilan dalam berkomunikasi selama handover merupakan bagian yang sangat penting untuk mencapai hasil perawatan yang diberikan kepada pasien secara optimal, serta menurunkan medical error diakibatkan kegagalan komunikasi oleh petugas kesehatan, didalamnya termasuk mahasiswa yang sedang menempuh stase praktik klinik. Sehingga diperlukan strategi pembe- lajaran tentang komunikasi efektif secara sistematis untuk meningkatkan keamanan dan perawatan berkualitas ${ }^{6}$.

Berdasarkan hasil penelitian didapatkan karakteristik responden pada rentang 18 - 21 tahun, dimana $63,1 \%$ berusia 20 tahun atau lebih. Usia merupakan hal yang penting karena mempengaruhi kematangan kognitif, perkembangan intelektual, kepribadian, dan emosional 7 . Hal ini sesuai dengan hasil penelitian dimana seluruh responen menunjukkan adanya perubahan kemampuan skill komunikasi efektif dari kurang baik sebanyak 96,6\% dan berubah menjadi baik seluruhnya setelah diberikan stimulasi berupa pembelajaran komunikasi efektif menggunakan metode role play. Usia 20-an merupakan masa puncak perkembangan intelektual sehingga proses pembelajaran akan mudah diterima dan lebih peka terhadap stimulasi yang diberikan?

Mahasiswa kebidanan tahun ke 2 dan ke 3 merupakan responden dalam penelitian ini yang telah mendapatkan teori komunikasi efektif dengan metode SBAR. Pengukuran kemampuan skill komunikasi efektif sebelum diberi perlakuan berupa role play menggunakan metode SBAR terdapat 28 orang dalam kategori kurang baik, terdiri dari 10 dari 11 orang (90\%) mahasiswa tahun ke 2 dan 18 orang (100\%) mahasiswa tahun ke 3. Setelah mendapatkan perlakuan terdapat pengaruh berupa peningkatan skill komunikasi termasuk dalam kategori baik ( $p 0.003$ ), terdiri $27,27 \%$ dari seluruh mahasiswa tahun ke 2, dan $83,34 \%$ dari seluruh mahasiswa tahun ke 3 .

Sesuai hasil penelitian yang dilakukan oleh Muspita $^{8}$ bahwa tingkat pendidikan merupakan level suatu proses yang berkaitan dalam mengembangkan semua aspek kepribadian manusia, termasuk didalamnya pengetahuan, nilai, sikap dan ketrampilan. Sehingga makin tinggi tingkat pendidikan yang dimiliki maka semakin tinggi pula kemampuan atau ketrampilan seseorang, serta lebih terbuka menerima adanya 
pembaharuan dan lebih mudah menyesuaikan diri. Akan tetapi, satu-satunya responden yang termasuk dalam kategori baik untuk skill komunikasi efektif merupakan mahasiswa yang sedang berada di tahun ke 2. Hal ini terjadi karena sebelum mendapatkan perlakukan berupa role play komunikasi efektif, responden telah mendapatkan materi teori komunikasi efektif metode SBAR, sesuai teori pengalaman Edgar Dele dalam Nursalam ${ }^{9}$ bahwa melihat dan mendengar juga mempengaruhi kemampuan mengingat walaupun hanya $20 \%$.

Hasil penelitian tentang perubahan skill komunikasi berdasarkan pengalaman melakukan handover dengan yang belum pernah melakukan handover menunjukkan adanya peningkatan walaupun tidak memberikan pengaruh yang signifikan. Terdapat peningkatan kemampuan komunikasi dalam kategori baik pada kelompok yang meliliki pengalaman handover sebanyak 14 dari 24 orang $(58,33 \%)$ dan pada kelompok yang belum memiliki pengalaman melakukan handover sebanyak 4 dari 5 orang (80\%).

Struktur sikap terdiri dari tiga komponen salah satunya adalah komponen konatif atau perilaku, dimana pengalaman pribadi merupakan salah satu unsur pembentuk sikap. Seseorang dalam menerima suatu pengalaman tidak terlepas dari pengalaman lain yang sudah diterima terlebih dahulu, sehingga respon terhadap pengalaman baru tidak serta merta dapat merubah perilaku. Hal ini nampak bahwa $41,78 \%$ dari kelompok yang memiliki pengalaman melakukan handover masih memiliki skill komunikasi efektif dalam kategori kurang baik setelah diberikan perlakuan berupa role play komunikasi efektif dengan metode $\operatorname{SBAR} \underline{10}$.

Perubahan skill komunikasi juga dapat dilihat pada sebagian besar (di atas 50\%) ditiap kelompok berdasar pengalaman melakukan handover, hal ini sesuai dengan pendapat yang disampaikan Azwar (2008) $\frac{10}{}$ bahwa perilaku dapat dibentuk dari pengaruh orang lain dan lembaga pendidikan. Orang disekitar kita merupakan salah satu komponen sosial yang ikut mempengaruhi sikap dan perilaku seseorang. Orang tersebut merupakan seseorang yang dianggap penting, diharapkan memberikan persetujuan pada setiap perbuatan, seperti orang tua, guru, orang yang memiliki status sosial lebih tinggi.

Selain itu lembaga pendidikan juga memberi peran dalam pembentukan sikap yang dapat merubah perilaku seseorang, karena lembaga pendidikan mengajarkan konsep dasar, termasuk konsep tentang komunikasi efektif $\stackrel{10}{ }$. Hal ini sesuai dengan hasil penelitian ini dimana sebagian besar responden mengalami perubahan perilaku yang nampak pada kemampuan skill komunikasi. Perubahan tersebut terjadi setelah diberikan serangkaian proses pembelajaran berupa role play oleh dosen pada saat proses pendidikan di lahan praktik.

\section{Skill komunikasi handover oleh mahasiswa kebidanan sesudah diberikan role-play komuniksai dengan metode S-BAR}

Skill komunikasi efektif mahasiswa mengalami peningkatan setelah mendapatkan pembelajaran dengan metode role play, yaitu dari $34.5 \%$ menjadi $62,07 \%$ termasuk dalam kategori baik setelah mendapatkan perlakuan pertama berupa pemberian materi komunikasi efektif dengan metode SBAR pada handover selama 100 menit dan dilanjutkan dengan role play menggunakan kasus fiktif. Setelah dilakukan simulasi menggunakan kasus nyata, seluruh responden mengalami peningkatan skill komunikasi termasuk dalam kategori baik.

Hal ini menunjukkan bahwa metode pembelajaran dengan menggunakan role play memberikan pengaruh yang signifikan pada peningkatan kemampuan mahasiswa, sesuai dengan penelitian yang dilakukan oleh Kesten (2011) ${ }^{6}$ bahwa role play menyebabkan mahasiswa dapat berfikir lebih kritis, meningkatkan kepercayaan diri, menstimulasi kemampuan mahasiswa dalam proses pembelajaran yang lebih tinggi. Role play merupakan salah satu metode pembelajaran berupa proses pengalihan atau transformasi ilmu pengetahuan dan teknologi untuk mendorong perkembangan intelektual, pembentukan watak, serta membentuk ketrampilan dan kemahiran yang dapat dilakukan melaui komunikasi yang baik dan efektif $\stackrel{11}{ }$.

Sesuai dengan teori kerucut pengalaman yang dikemukakan Edgar Dale bahwa pengalaman langsung dapat memberikan kemampuan mengingat hingga $70 \%$, sehingga dapat mendukung kemampuan untuk merubah perilaku lebih besar. Sehingga role play merupakan salah satu proses pembelajaran yang memberikan pengalaman langsung dengan menggunakan situasi nyata untuk memahami konsep, prinsip dan keterampilan, dan memberikan dampak pada perubahan sikap 
maupun perilaku . Begitu juga pada penelitian yang dilakukan oleh Chan ${ }^{4}$ yang menyatakan bahwa role play merupakan metode dari pembelajaran Problem Base Learning (PBL) yang merupakan penjabaran dari SCL merupakan dengan menggunakan pengalaman yang mencerminkan situasi kehidupan nyata, sehingga PBL menjadi pilihan metode pembe-lajaran yang banyak digunakan oleh intitusi pendidikan kesehatan, dan merupakan salah satu metode pembelajaran yang dapat meningkatkan kreatifitas, motivasi belajar, kemampuan menyelesaikan masalah, terutama dalam memahami kebutuhan pasien dan keluarga.

Sama dengan hasil penelitian Whetehair 12 menyatakan bahwa role-play memberikan peningkatan percaya diri, keaktifan, mengembangkan ketrampilan, meningkatkan motivasi dalam menerima tanggung jawab, serta kemampuan dalam bekerja sama pada mahasiswa. Akan tetapi, peningkatan skill komunikasi ini menunjukkan hasil adanya peningkatan menjadi baik pada pengukuran post test ke 2 yang dilakukan satu minggu setelah diberikan perlakuan, hal ini terjadi karena memori tentang penerapan komunikasi efektif masih segar di ingatan. Hal ini sesuai dengan teori Aus dalam Rakhmat ${ }^{13}$ menyatakan bahwa memori akan hilang atau memudar karena waktu, maka memori terhadap sesuatu hal akan kuat jika dilatih terus menerus.

\section{Pengaruh role-play handover oleh mahasiswa kebidanan terhadap skill komuniksai metode S-BAR}

Sebelum dilakukan pembelajaran dengan role play beberapa mahasiswa tidak mengetahui apa yang harus dilakukan pada saat handover. Sedangkan pada mahasiswa yang memiliki pengalaman melakukan handover, tidak semuanya mengetahui langkah-langkah handover, hal ini nampak bahwa pada item lembar observasi skill komunikasi efektif seluruh tahapannya dilaksanakan kurang dari 30\%. Penggunaan komunikasi efektif dengan metode SBAR menjadikan penyampaian informasi lebih sistematis dan terarah, isi informasi lebih jelas, waktu yang dibutuhkan juga lebih singkat. Hal ini nampak bahwa setelah dilakukan pembelajaran penggunaan komunikasi efektif metode SBAR, mahasiswa mampu memberikan informasi secara sistematis ditunjukkan dengan seluruh item 1-7 pada lembar observasi skill komunikasi efektif dilaksanakan secara lengkap lebih dari $44 \%$ yang sebelumnya hanya dibawah 13,8 \% yang melaksanakan secara lengkap.

Hasil ini menunjukkan bahwa metode SBAR dapat meningkatkan kemampuan mahasiswa dalam skill komunikasi efektif, sesuai pernyataan Velji 14 bahwa SBAR dapat meningkatkan kemampuan komunikasi antar anggota tim baik pada sesame profesi maupun antar profesi, yang akan mempengaruhi perbaikan budaya keselamatan pasien. Kemampuan skill komunikasi pada pelaksanaan handover setelah dilakukan pembelajaran role play terdapat peningkatan. Persiapan handover berupa mempersiapkan diri dan informasi yang akan disampaikan sebelum diberi role play dari $10,3 \%$ menjadi $82,8 \%$ yang melaksanakan dengan lengkap. Sedangkan untuk langkah persiapan handover berupa menjelaskan identitas pemberi handover dari 58,6\% berubah menjadi 6,9\% yang tidak melakukan langkah ini. Hal ini juga nampak pada pelaksanaan handover itu sendiri, dimana sebelum diberikan role play, informasi yang diberikan hanya mengenai keadaan saat ini saja tanpa menyertakan riwayat atau kondisi yang menjadi latar belakang pasien tersebut mendapat perawatan. Kondisi ini tentu saja dapat mengakibatkan tingginya medical error atau pemberian perawatan yang tidak efektif, mengakibatkan peningkatan biaya perawatan.

Langkah ke tiga pada handover berupa mengklarifikasi informasi yang disampaikan, sebelum diberikan role play $34,5 \%$ tidak melakukan langkah ini, yang terjadi disini adalah bentuk komunikasinya cenderung berupa passive communication sehingga hanya menerima informasi. Selain itu keadaan ini terjadi karena pemberi handover tidak memberikan kesempatan pada penerima handover untuk mengklarifikasi informasi yang diperoleh. Kondisi tersebut dapat terjadi karena pemberi handover berasumsi bahwa penerima handover memiliki kemampuan dan pengetahuan yang sama, tanpa memperhatikan seberapa banyak penerima handover memahami informasi yang diterima, atau pemberi handover memberikan informasi sebanyak-banyaknya dan mendominasi proses komunikasi (egocentric heuristic) tanpa memperhatikan kesiapan si penerima handover ${ }^{15}$. Sedangkan dalam komunikasi efektif salah satu hal yang penting adalah mengkonfirmasi informasi yang diterima, sehingga meminimalisir adanya salah persepsi $1 \frac{16}{}$. 
Setelah mendapatkan role play mahasiswa menjadi memahami tahap-tahap yang harus dilalui dalam melaksanakan handover. Persiapan berupa mengumpulkan informasi tentang perkembangan hasil perawatan pasien dan riwayat perawatan sebelumnya sudah disiapkan, sehingga pada tahap pelaksanaan handover kelengkapan informasi sudah disiapkan, termasuk antisipasi terhadap pertanyaan yang mungkin diajukan oleh penerima handover, dan pelaksanaannya menjadi lebih efektif dan efisien, hal ini terjadi karena informasi lebih fokus, waktu yang digunakan lebih sedikit.

Sejalan dengan hasil penelitian yang dilakukan oleh Fitria $\stackrel{11}{ }$ menyatakan bahwa metode pelatihan komunikasi efektif metode SBAR dengan menggunakan demonstrasi yang dilakukan secara langsung, menjadikan peserta mendapatkan gambaran lebih nyata, sehingga lebih mudah untuk dipahami dan meningkatkan kemampuan psikomotor. Begitu juga hasil penelitian yang dilakukan oleh Wayan 17 bahwa edukasi dapat berupa pemberian role play dapat meningkatkan pengetahuan, keteram-pilan, serta menimbulkan perubahan perilaku yang lebih baik. Informasi yang disampaikan pada saat handover menjadi lebih efektif dan efisien akan meningkatkan budaya patien safety. Dewi $\frac{18}{}$ menyampaikan bahwa komunikasi menjadi salah satu hal penting dalam pelaksanaan pelayanan, karena keselamatan pasien tidak terlepas dari penentuan serta pelaksanaan standar dan prosedur komunikasi efektif.

Berdasarkan paparan di atas maka dapat didigunakan sebagai jawaban terhadap hipotesis dalam penelitian ini bahwa role-play SBAR dapat mempengaruhi peningkatan skill komunikasi handover pada mahasiswa kebidanan. Sejalan dengan penelitaian yang dilakukan oleh Gobel bahwa efektifitas handover dipengaruhi oleh ketersediaan informasi, ketersediaan kesempatan untuk kontak langsung antar petugas, adanya pelatihan dan penggunaan standar pelaksanaan handover maupun komunikasi efektif, serta penggunaan tehnologi informasi seperti SBAR. $\underline{20}$

Penelitian ini menunjukkan bahwa metode pembelajaran dengan menggunakan role-play merupakan salah satu metode PBL yang dianjurkan. Role play yang diberikan tidak hanya dilakukan dengan menggunakan kasus fiktif yang dilaksanakan di skill laboratorium, akan tetapi diikuti dengan praktik di lahan (layanan kesehatan), supaya mendapatkan gambaran nyata. Hal ini sejalan dengan teori kerucut pengalaman
Edgar Dale bahwa pengalaman langsung dapat memberikan kemampuan mengingat hingga 70\%, sehingga dapat mendukung kemampuan untuk merubah perilaku lebih besar-9. Sejalan dengan pendapat Iyer ${ }^{19}$ bahwa role play dapat menjadi pilihan metode yang tepat untuk latihan komunikasi yang sangat berharga, karena pada proses komunikasi kadang muncul perasaan tidak dipahami oleh lawan bicara sehingga muncul reaksi yang tidak sama. Faktor ini kadang bisa menjadi hambatan untuk dapat mende-ngarkan atau berkomunikasi secara efektif.

Penggunaan standar prosedur untuk melaksanakan handover menjadikan mahasiswa lebih memahami langkah-langkah dalam melaksanakan handover. Selain itu penerapan metode komunikasi efektif dengan SBAR merupakan salah satu standar komunikasi yang baik untuk diterapkan dan diajarkan pada mahasiswa. Hal ini dikarenakan metode SBAR menjadikan mahasiswa lebih mengerti bagaimana cara mengomunikasikan suatu kondisi pasien pada saat handover baik pada sesame profesi maupun antar profesi.

Sejalan dengan Gobel 20 bahwa standar prosedur dan penggunaan tehnologi informasi, seperti SBAR, akan sangat mempengaruhi efektifitas handover. Penggunaan SBAR ini menjadikan maha-siswa lebih meningkatkan pemahaman terhadap suatu kasus, karena harus dapat menjelaskan kondisi pasien saat ini, serta latar belakang terhadap perawatan yang diberikan maupun riwayat kesehatan yang berkaitan, selanjutnya dilatih untuk meningkatkan kemampuan menganalisis kasus berdasarkan pengamatan, dan memberikan sarannya dari apa yang dia percaya akan menjadi tindakan yang terbaik. Hal tersebut sesuai dengan pendapat Iyer ${ }^{19}$ bahwa SBAR adalah model yang lebih baik karena dapat diterapkan untuk setiap situasi, serta pada saat handover. SBAR memfasilitasi terbangunnya pola komunikasi dalam system, dan melalui rekomendasi atau melalui tindakan akhir akan membangun terbentuknya kerjasama dalam kelompok.

\section{Pengaruh role-play handover oleh mahasiswa kebidanan terhadap kemampuan melaksanakan handover}

Pelaksanaan handover terdiri dari empat tahapan..$\underline{5}$ Berdasar hasil penelitian tahapan pertama berupa pra kerja (pra handover) sudah dilakukan dengan baik hal ini nampak bahwa sebelum diberi role- 
play skor pada lambar lembar observasi menunjukkan adanya kenaikan skor. Responden telah menyiapkan informasi yang akan diberikan pada petugas (responden yang lain) yang akan menggantikan shif jaga berikutnya. Tahap ini pula menunjukkan baik pemberi dan penerima handover telah menyiapkan diri untuk melaksanakan handover, sehingga lebih fokus pada informasi yang disampaikan maupun diterima.

Akan tetapi penyiapan informasi ini masih menggunakan catatan yang dibuat sendiri oleh responden, berdasar dari rekam medis pasien. Hal ini dapat menimbulkan kekeliruan informasi karena kesalahan penerjemahan terhadap hasil yang diperoleh dari rekam medis. Sesuai dengan penelitian yang dilakukan oleh Joffe et.al. disebutkan bahwa kegagalan komunikasi dapat terjadi karena penyam-paian informasi yang tidak tepat, dengan hanya menyampaikan kesimpulan dari hasil pemeriksaan, bukan memberikan secara jelas hasil pemeriksaan secara langsung. $\underline{21}$

Tahap ke dua adalah handover itu sendiri, yaitu penyampaian informasi telah disiapkan kepada petugas penerima handover. Tahap ini diikuti oleh seluruh responden yang bertugas, baik yang akan digantikan, maupun yang akan menggantikan jaga. Sehingga seluruh petugas memperoleh informasi yang sama dan memiliki kesempatan untuk merespon maupun mengklarifikasi informasi yang diberikan oleh petugas pemberi handover, termasuk menanyakan tindakan yang sudah diberikan maupun yang masih direncanakan, dimana tahap ini termasuk dalam tahap ke tiga pelaksanaan handover.

Kemampuan responen untuk merespon informasi yang ada juga mengalami peningkatan, berdasal lembar observasi nampak pada item tujuh berupa konfirmasi informasi terjadi peningkatan skor sebesar 25. Kemudian dilanjutkan tahap ke empat berupa penerimaan pengalihan tanggung jawab. Pelaksanaan handover dengan mempersiapkan informasi didukung dengan catatan dan penggunaan rekam medis akan menurunkan kejadian hilangnya informasi yang harus disampaikan. Hal ini sesuai penelitian yang dilakukan oleh Friesen et.al. $\underline{16}$ bahwa penggunaan lembar catatan dan rekam medis kemudian disampaikan secara lisan akan meningkatkan ketepatan informasi hingga 96$100 \%$. Dengan demikian, seluruh petugas baik yang digantikan maupun menggantikan mengikuti proses handover akan dapat menurunkan medical error sehingga penerapan patient safety dapat meningkatkan. Hal ini sejalan dengan penelitian yang dilakukan oleh Wayan ${ }^{17}$ bahwa kebutuhan akan informasi yang adekuat dan spesifik serta kontribusi petugas kesehatan tetap menjadi faktor penentu dalam menciptakan budaya keselamatan pasien.

\section{SIMPULAN}

Role-play handover oleh mahasiswa kebidanan memberikan pengaruh pada skill komuniksai metode SBAR, dimana nilai $\mathrm{P}<0,000$ dengan demikian dapat disimpulkan bahwa terdapat perbedaan yang bermakna pada skill komuniksi efektif metode SBAR saat handover sebelum dengan sesudah diberikan pembelajaran dengan role-play.

\section{DAFTAR PUSTAKA}

1. Manser,T., 2011. Effective handover communication: An overview of research and improvement efforts 25, 181-191. Diakses $31 \mathrm{Mei}$ 2014

doi:10.1016/j.bpa.2011.02.006https://www.resear chgate.net/publication/51105937

2. Frelita, G., Silitongah, D.S., Situmorang, T., Tahjoo, A., Oeswadi, J., Tandiono, E., Sutoto, 2011. 'Joint Commission International Standar Akreditasi Rumah Sakit', 4th ed. PT Gramedia Indonesia

3. Cynthia D., B., Gayle, K., 2009. 'Collaborative Communication: Integrating SBAR to Improve Quality/Patient Safety Outcomes'. J. Healthc. Qual. Vol. 31, No. 5. Diakses tanggal 27 mei 2014 http://www.ncbi.nlm.nih.gov/ pubmed/19813557

4. Chan,Zenobia C.Y, 2012, Role-playing in the problem-based learning class, NEP Diakses $\begin{array}{llll}\text { tanggal } & 9 & \text { Mei } & 2014\end{array}$ http:/www.ncbi.nlm.nih.gov/pubmed/21601528

5. Dahlan,M.Sopiyudin, 2013,'Statistik Untuk Kedokteran dan Kesehatan'. Salemba Medika. Jakarta

6. Kesten, Karen S., 2011, 'Role Play Using SBAR Technique to Improve Observed Communication Skill in Senior Nursing Students, J. Nursing 
Education Vol 50 No 2, diakses tanggal 5 September

https://www.researchgate.net/publication/497329

78

Role-lay_Using_SBAR_

Technique_to_Improve_Observed_Communicati on_Skills

7. Jahja yudrik, 2011,'Psikologi Perkembangan'. Kencana Prenada Media Group, Jakarta

8. Muspita Mutiana, 2014,'Kepatuhan Perawat Dalam Melaksanakan Standar Prosedur Operasional Pemasangan Infus Di Rumah Sakit PKU Muhammadiyah Gombong'

9. Nursalam, 2008, Konsep dan Penerapan Metodologi Penelitian Ilmu Keperawatan, Salemba Medika, Jakarta.

10. Azwar, Saifudin, 2008, 'Sikap Manusia Teori dan Pengukurannya', Pustaka Pelajar, Yogyakarta

11. Fitria, Cemy Nur, 2013,' Efektifitas Pelatihan Komunikasi SBAR dalam Meningkatkan Motivasi dan Psikomotor Perawat di Ruang Medikal Bedah RS PKU Muhammadiyah Surakarta, Prosisding Konfrensi Nasional PPNI Jawa Tengah

12. Whitehair Leeann, O'Reilly Meg, 2010, 'Media supported problem-based learning and role-play in clinical nurse education' CH Steel, MJKeppell, P Gerbic \& S Housego (eds), Curriculum, technology and transformation for an unknown future: proceedings of ascilite 2010, Sydney, NSW, 5-8 December, University of Queensland, Brisbane

13. Rakhmat, Jalaludin, 2003, 'Psikologi Komunikasi', PT Remaja Rosdakarya, Bandung

14. Velji Karima, 2008,'Effectiveness of an Adapted SBAR Commubication Tool for a Rehabilitation Setting', Healthcare Quarterly, Vol 11 Diakses tanggal $11 \quad$ Juni 2015 http://www.ncbi.nlm.nih.gov/pubmed/18382165

15. Riesenberg, L.A.,2012. 'Shif to Shift Handoff Reasearch: Where Do We Go From Here?' J. Gd. Med Educ 4. Diakses tanggal 15 Oktober 2015 http://www.ncbi.nlm.nih.gov/pmc/articles/ PMC3312531/

16. Friesen, M. A., White, S. V., \& Byers, J. F. (2008). 'Handoffs: Implications for nurses', Patient safety and quality: An evidence-based handbook for nurses (chapter 34). Diakses tanggal 25 November 2015 http://www.ncbi.nlm.nih.gov/books/ NBK2649/pdf/Bookshelf_NBK2649.pdf
17. Wayan, Ananta Arya Wijaya, Sukadarma, Asdiwinata, 2014,' Pengaruh Edukasi Teknik SBAR Saat Handover Terhadap Penerapan Sasaran International Patient Safety Goals 2 (Ipsg 2) Di Ruang Rawat Inap Nakula Dan Sahadewa Rsud Sanjiw Ani Gianyar'

18. Dewi, Mursida, 2012,' Pengaruh Pelatihan Timbang Terima Pasien Terhadap Penerapan Keselamatan Pasien Oleh Perawat Pelaksana di RSUD Raden Mattaher Jambi'Jurnal Health \& Sport, Volume 5, Nomor 3.

19. Iyer, Patricia W.,2010, 'SBAR: Creating Clear Comunication', Med League Support Services, Flamington.

20. Gobel, B., Zwart, D., Hesselink, G., Pinjnenborg, L., Barach, P., Kalkman, C., Johnson, J., 2012. 'Stakeholder Perspective on Handover Between Hospital Staff and General Practitioners: An Evaluation Trough The Microsystems Lens'. BMJ Qual. Dan Saf. Diakses tanggal 10 September 2015

http://www.ncbi.nlm.nih.gov/pubmed/23118408

21. Joffe Erel, Turley James P, Hwang Kevin O, Johnson Todd R, Johnson Crag W, Berstem Elmer V,2013, ' Evaluation of a Problem-Specific SBAR Tool to Improve After-Hours Nurse-Physician Communication' The Joint Commission Journal on Quality and Patient Safety Number 11, 495507. Diakses tanggal 31 Mei 2014 http://psnet.ahrg.gov/resource.aspx/ resourceID $=26967$ 